\title{
Medical research conduct and publication during higher education in Syria: attitudes, barriers, practices, and possible solutions
}

\author{
Ibrahem Hanafi ( $\square$ lbrahem.W.Hanafi@gmail.com ) \\ Damascus University \\ Luma Haj Kassem \\ University of Aleppo \\ Mouaz Hanafi \\ Damascus University \\ Sulafa Ahmad \\ Tishreen University \\ Ola Abbas \\ Damascus University \\ Mohammad Younis Hajeer \\ Damascus University \\ Fares Alahdab \\ Mayo Clinic
}

\section{Research Article}

Keywords: Research contributions, publication practices, postgraduate students, Syrian crisis, residents' attitudes, institutional barriers, resident physicians, pharmacy postgraduates, dentistry postgraduates

Posted Date: June 7th, 2021

DOI: https://doi.org/10.21203/rs.3.rs-382753/v2

License: @) (i) This work is licensed under a Creative Commons Attribution 4.0 International License. Read Full License 


\section{Abstract}

Introduction:

The huge workload on doctors especially residents, who are the main healthcare providers in public hospitals, in addition to the vanishing incomes and lack of personal safety during the decade-long Syrian crisis, led to further hurdles for the focus on research. Postgraduate students in the medical and paramedical fields must conduct original research projects as part of their graduation requirements. However, that does not reflect on the research publications coming from Syria.

Methods:

A nation-wide cross-sectional study targeting medical, dental, and pharmacy postgraduate students who are at the phase of planning for their required projects. The questionnaire aimed to capture their attitudes towards research, perceived barriers, and previous research experiences.

Results:

The sample consisted of 429 residents representing about $22 \%$ of the target population. Nearly all the participants had positive opinion towards the important role of medical research and the significance of their participation. Agreement was also clear regarding perceived barriers including the lack of adequate training, and research facility. Seventy-one percent of the participants were not involved in any research before the time of their master theses, less than $13 \%$ of them had submitted an article for publication, and less than $5 \%$ had submitted more than one paper. Poor internet connectivity and poor reading and writing English skills were decisive negative factors in previous research experiences. Mentors' support and self-paced learning of research skills had a significant positive impact on students' research contributions with odds ratios of 2.04 [1.02-4.06] $(P<0.001)$ and $2.68[1.48-4.84](P<0.001)$ respectively.

Conclusion:

The attitudes of postgraduate students towards research were quite positive but hindered by several obstacles. Further integration of research practical training in the curricula, allowing long-distance mentoring, enhancing collaboration between peers, as well as narrowing the distance between students and mentors may significantly boost research productivity in Syria despite the conflicts.

\section{Introduction}

Healthcare providers in developing countries need to find innovative solutions to overcome challenges by performing research projects that are feasible in their circumstances. The ten-year-long Syrian crisis has deeply affected all aspects of Syrians' lives, especially healthcare and education. Over half of their healthcare facilities became out of service after only five years of war, because of the repeated attacks and bombing [1], which became even worse over time. The decline in healthcare infrastructure, along with the rising numbers of war-related victims, directly and indirectly led to an increased burden on the other remaining hospitals and their staff who had to increase their efforts and the time spent working significantly. The global surge in physician and medical staff burnout (e.g. in the US [2]) not only affects Syrian medical personnel, but also it affects them at a staggeringly more severe level. This erodes their skills and productivity during work and leaves them depleted and with less work-life satisfaction [3]. In Syria, this problem is more evident among residents during the crisis and the percentage of this debilitating syndrome was estimated to be among the highest worldwide [4]. This is also aggravated by the increase in workplace violence in Syrian hospitals, which triggered physiological stress and loss of confidence among resident doctors [5]. These serious socio-economic situations, in addition to the vanishing income and lack of personal safety, caused half of the medical personnel to flee Syria by 2016 [6-8]. Those who stayed in Syria are still facing lifestyles that leave them with no time or enthusiasm to get involved in research activities [8]. 
Medical, dental, and pharmacy residents are considered the main possible contributors to research conduct in Syria for many reasons. Firstly, a research project is a requirement for their graduation. Secondly, they are in direct contact with patients as doctors and dentists or they spend most of their time in university labs as pharmacists. Thirdly, they have less duties and responsibilities and more time to investigate than the elder practicing specialists. Finally, they see a wide variety of cases because of working in central and academic health centers with a very high flow of patients. However, the falling numbers of available medical personnel and the high workload are factors hindering the increase in research output from Syria, which was already lower before the Syrian war in comparison to other wealthier Arab countries $[9,10]$.

A recent report about the problems and challenges of medical research in Syria demonstrated that the most important barriers were the limited financial support, the lack of research-related skills, the lack of research equipment and the absence of stable internet and electricity [11]. Another report shed light on the attitudes, barriers, and practices of medical research among medical students in Damascus University and had found comparable results [12]. However, there is a lack of comprehensive evidence regarding research productivity of postgraduate medical and paramedical students in all of Syria [13]. The aim of this study is to investigate attitudes towards research, perceived barriers, current needs, and previous research experiences of postgraduates in all medical and paramedical fields in Syria, and to compare them against different demographic determinants to lay the groundwork for suggesting fact-based solutions.

\section{Materials And Methods}

\section{Participants:}

The Ministry of Higher Education in Syria runs eight universities, including seven schools of medicine. However, only three of them have higher education programs, which are based in Damascus (Damascus University), Aleppo (Aleppo University), and Latakia (Tishreen University). Syria also has three schools for pharmacy and three for dentistry with higher education programs in the aforementioned cities, in addition to a fourth school for pharmacy in Homs (Al-Baath University), and a fourth school for dentistry in Hama. There is also a virtual master's program for medical education from the Syrian Virtual University. All these programs were considered postgraduate master programs in the Syrian higher education system and they required the students to conduct and defend an original research study (thesis) in order to graduate. However, generally it is not obligatory to publish their work in any journal. The target participants in this study are specifically students of these programs who are at the phase of planning for their research studies. This was the best time point to investigate the attitudes towards conducting a high-quality study and the barriers for publishing this work later. The year of planning and registering these master theses differed between specialties and disciplines due to the different lengths of the programs (2-6 years). However, it is generally considered the third year for the schools of medicine, the second for dentistry and the first for pharmacy. A small proportion of students prepared their research proposals in the year preceding or following the defined year above, and those were also included in the sample.

\section{Study design and data collection:}

This cross-sectional study targeted postgraduate students at all Syrian medical, dental, and pharmacy schools with higher education programs, and the data were collected via an online questionnaire created using Google Form. First, chief residents in each department shared an invitation to an online extracurricular eight-hour-workshop with all the residents and fellows. The workshop objectives were to practically provide peer-support to residents in preparing their upcoming research projects. Then the form was sent to those who showed interest in that support individually. Three days later, a reminder was sent to them, and at the end, all the interested students $(n=429,100 \%)$ completed the questionnaire. The process of data collection took place over two weeks in July 2020. Participants were informed about the aims of the study and were asked to provide their consent to participate at the beginning of the questionnaire. Participation was completely voluntary, with the assurance of confidentiality. Ethical approval for this study was obtained through Damascus University, and it complies with the declaration of Helsinki 1975, as revised in 2008.

Page $3 / 20$ 


\section{The questionnaire:}

This study used a questionnaire developed in a previous study to investigate attitudes, barriers, and practices toward scientific research among undergraduate medical students in Damascus [12]. However, some of the terms were modified to suit higher education postgraduate students. The questionnaire was in Arabic, which is the mother language for all participants. The final version of the questionnaire was first piloted on ten participants from different specialties of the target group to confirm that all responders can follow the instructions and answer the questions without concerns regarding the language, understanding, consistency, and structure.

The first section in the questionnaire included questions about the participants' demographic data and self-reported English proficiency. The second section used a 5-point Likert scale to assess participants' beliefs and attitudes towards medical research, as well as the current barriers for conducting medical research. The third section included multiple-choice questions to capture self-reported participants' sources of training, levels of supervisors' encouragement, and possible previous research experience. Participants could refer to official intracurricular university modules or to self-paced extracurricular trainings. Otherwise, they reported not receiving sufficient training. The fourth additional section focused on participants' needs to plan, conduct and publish their master theses in peer reviewed journals, as well as a question to indicate their enthusiasm for attending trainings that focus on these needs.

\section{Statistical analysis}

The data were exported from the online questionnaire to Microsoft Excel 365 version 2011 (year 2020), and then imported into the Statistical Package for the Social Sciences version 23.0 (SPSS Inc., Chicago, IL, United States).

The year of study was coded according to the usual year of registering the research proposal in each specialty into three categories: "Early registration", "Normal registration", and "Late registration". The different human medicine specialties were grouped into four categories: a) Internal medicine and psychiatry; b) Surgical specialties, pediatrics, obstetrics, and gynecology; c) Otolaryngology, dermatology, and ophthalmology (Clinics Specialties); d) Other medical specialties including radiology, pathology, and laboratory medicine (Translational Specialties). Chi-square and Fisher's exact tests were used to investigate categorical associations combined with odds ratios (ORs) and corresponding 95\% confidence intervals (Cls). Mann-Whitney test was used to compare the attitudes and barriers ranks between groups. An alpha value of 0.05 was used to determine the threshold of statistical significance, with the usage of Bonferroni correction when needed to adjust for multiple testing. Additionally, binary logistic regression analysis was used to investigate prediction models of attitudes, barriers, and demographic characteristics regarding prior participation in research and submission of manuscripts for publication.

\section{Results}

\section{Demographic characteristics:}

The sample consisted of 429 postgraduates who showed interest in the suggested extracurricular support. They represented $21.5 \%$ out of the whole targeted population of nearly two thousand students actively working or studying under the medical, dental, and pharmacy higher education programs in Syria. Response rate was the highest for the translational specialties (46.1\%), followed by internal medicine and out-patient clinic specialties (34\% each). Surgical specialties came lowest with a response rate of only $11 \%$. Damascus, Latakia and Aleppo had the largest universities and they contributed to more than $90 \%$ of the sample, and 267 participants (62.2\%) were females. Nearly half of the respondents did not consider the training they had already received regarding medical research sufficient to rely on, and $332(77.4 \%)$ of them had received encouragement by their mentors to conduct research (Table 1).

\section{Attitudes towards research and its perceived barriers:}


The vast majority of the participants showed strong inclination to believe that research plays an important role in the medical fields, that research methodology should be a part of their curricula, and that participating in it was important for them as students and as part of their career plans. However, only 47 participants $(10.9 \%)$ agreed with the statement that "medical research does not require a lot of money". Regarding the barriers for research, over $80 \%$ agreed that the inadequate training in research methodology and in reading and evaluating research articles, as well as the lack of research facilities, were important obstacles. Similarly, around 70\% faced barriers such as the lack of research opportunities, the absence of reward, and the unavailability of research mentors. Lack of time, difficulties in accessing medical journals and in obtaining ethical and scientific approvals for research projects were also important factors to $60-65 \%$ of the participants (Figure 1).

\section{Conducting research and publishing scientific papers:}

Seventy-one percent of the included participants had not worked on any research project before the time of their master theses, and $17.5 \%$ of the rest had only worked on one project. However, less than $13 \%$ reached the phase of submitting an article for publication, and less than $5 \%$ submitted more than one paper. A third of the reported projects were single case reports or case series. "An important skill to learn" and "to relay scientific information" were the most common reasons for conducting research, while only $2.5 \%$ did not find research contribution important at all. The most common reasons for not conducting any research were the lack of guidance and supervision (41.3\%) as well as the lack of opportunities (36.7\%). Only seventy-five out of the 172 studies that the responders contributed to were submitted for publication (43.6\%). However, the rate for basic laboratory-based projects was about $25 \%$. Only $20 \%$ of the participants who reached submission reported that all their submissions were eventually published. Submission of research articles was driven mostly by the necessity for relaying information (36.2\%) and career progression (34\%). On the other hand, the most important reasons for not submitting scientific papers for publication were insufficient academic writing experience (30.3\%) and the lack of guidance and supervision (27.3\%; Table 2).

\section{The impact of attitudes and perceived barriers on previous research experiences:}

Participants who reported submitting research articles for publication or even just participating in research projects previously had significantly higher attitudes towards research. However, only the barriers of lack of training and mentors' support were significantly higher in the group who had never participated in research. In addition to them, language limitations and the poor access to medical literature were higher in the group who had never submitted a manuscript for publication. Logistic regression analysis of the attitudes was significant regarding participation $\left(R^{2}=5.5 \%, P=0.005\right)$ and submission of research studies $\left(R^{2}=8.3 \%, P=0.001\right)$. A similar analysis regarding barriers was also significant for both participation $\left(R^{2}=6.5 \%\right.$, $P=0.030)$ and submission $\left(R^{2}=10.4 \%, P=0.006\right)$. However, only two attitude items and one barrier were revealed as significant independent predictors towards the submission of manuscripts to peer-reviewed journals (Table 3 ).

\section{Demographic factors contributing to participation in research and publishing scientific papers:}

Contributing to and submitting papers for publication varied significantly among specialties but were homogenous in between genders and universities. Internet connectivity as well as reading and writing English skills had significant associations with having contributed to medical research $(P=0.010,0.008$ and $<0.001$ respectively). However, only writing skills and internet connectivity showed statistically significant relations with submission of research articles $(P<0.001$ and 0.004 respectively). The results also illustrated a statistically significant association between research contribution on one side and the source of research training and the support of mentors on the other side ( $P<0.001 \mathrm{for}$ both). The same trend held true for the association between the source of training and submission attempts to peer reviewed journals $(P<0.001)$. Students relying on self-training 
in research skills were 2.68 [1.48-4.84] times more likely to conduct research and 3.64 [1.62-8.19] times more likely to submit it in comparison to the rest of the sample $(P<0.001)$. The latter were even higher than the odds ratio of participation and submission in students who had reported being trained properly by a formal curriculum. On the other hand, students who were encouraged by their mentors were 2.04 [1.02-4.06] times more likely to have conducted research than the rest of the sample $(P<0.001)$, but that did not induce significant impact of the rate of submitting manuscripts $(P=0.083$; Table 4$)$.

A binary logistic regression analysis of the demographic characteristics revealed a significant prediction model for research participation $\left(\mathrm{R}^{2}=25.1 \%, P<0.001\right)$ and submission $\left(\mathrm{R}^{2}=28.4 \%, P<0.001\right)$. Studying at Tishreen University, specializing in pharmacy, dentistry, or medical education, being encouraged by mentors, having good English writing skills, and following self-paced or intracurricular trainings were significant independent predictors for participation in research projects. The latter two in addition to having a high-quality internet connection were, on the other hand, significant independent predictors of submitting manuscripts for publication (Table 4).

\section{Research needs for preparing master theses:}

Most of the participants (93.5\%) reported that they were in need and enthusiastic to attend trainings to plan, conduct, and publish their studies. With regards to the components of this proposed training, academic writing was the most commonly reported need (91.2\%), followed by the peer review processes (86.8\%), and preparing research proposal (85.8\%; Figure 2).

\section{Discussion}

With the aforementioned findings and the large representative sample, this study could successfully uncover postgraduate students' attitudes towards research and their perceived barriers hindering the publication of the conducted projects. It could also investigate the contributions of these factors and the demographic characteristics towards previous research experiences in order to identify the main gaps and to suggest fact-based solutions to improve medical research productivity in Syria.

Participants in this survey study reported high positive attitudes towards medical research similarly to what was reported in Saudi Arabia [14], which is one of the leading Arab countries in medical research conduct $[15,16]$. These attitudes were also higher in comparison to the attitudes of medical students at Damascus University, which were captured in 2018 using the same tool of measurement [12]. However, this contrasted with two studies from Iran and Pakistan that reported lower attitudes towards research for postgraduates in comparison to undergraduates $[17,18]$. The reasons for that in the Syrian sample might have been that participants were in daily contact with the uncertainties in disease management and the limitations of relevant guidelines, along with the limited resources during the crisis [19]. The main motivations for the participants' willingness to contribute to research while suffering from the devastating consequences of this war were to relay evidence-based knowledge and to develop a flourishing academic career (Table 2).

These attitudes were faced with a wide variety of barriers, the most important of which was the absence of adequate training of research methodology. This reason had also been singled out as the main barrier in a sample of nearly 200 medical residents in Saudi Arabia [14]. It is worth noting that all the included programs had at least one module for research methodology during the first, second or third year of higher medical education. However, these modules were deemed ineffective in equipping students with the necessary tools to conduct research independently. The unavailability of research mentors was another important obstacle reported by our studied group of students. This finding was in line with several other studies even in the most productive countries in medical research in the area such as Saudi Arabia and Iran [14, 18]. However, that did not clearly reflect the true importance of this limitation, because lack of time, funding and reward as well as stress were factors of more importance than mentors' unavailability to the Saudi, Pakistani and Iranian participants [14, 18, 20]. On the contrary, the surveyed Syrian students put the need for mentors' support prior to these other barriers. This can be explained by the findings of Khan et al. who reported that $65.2 \%$ of Pakistani postgraduate medical trainees thought they could plan and conduct research without supervision, and only $11 \%$ of their participants considered the unavailability of mentors as a 
hindrance [20]. Therefore, students' knowledge, experience, and confidence in this sample seemed much higher than the ones reported by our participants.

Although lack of time remained an important limitation to medical research in Syria, especially during the current war [21], it was more significant to resident physicians worldwide [22-24]. This might explain why participants seemed to focus more on quick short studies that require less methodological knowledge, less support by mentors, and less or no funding, such as case reports and cross-sectional studies. Nevertheless, the number of published case reports remained modest $[25,26]$, and these studies were less likely to fulfill the unmet research needs of the Syrian healthcare system.

The variability of participation in medical research in our sample could be better explained by the demographic characteristics than the self-reported attitudes and perceived barriers. This might be due to students' inadequate awareness of the factors that carry the most impact on hindering or boosting research productivity, as well as the lack of comprehensive advice on how to fill in the gab and help postgraduate students to publish (i.e., the aim of our survey). The extensive and overall analysis achieved in this study could reveal specific institutional and individual recommendations that should be able to mitigate these barriers and boost the positive attitudes allowing for the publication of at least the projects being conducted as a requirement for graduation.

Syrian institutions should implement more practical in-house workshops to supplement the current research curriculum, which was rated insufficient by our participants. For instance, a remote-site for the Introduction to the Principles and Practice of Clinical Research (IPPCR) course, presented by the U.S. National Institutes of Health (NIH) [27], was established in Syria since 2015 and more than four annual workshops based on this course have been delivered so far $[13,28]$. Online workshops, on the other hand, can provide a more affordable, widely accessible, and flexible option that still leads to comparable results [13, 2932]. These educational events should be recorded and published afterwards for self-paced learning, and should cover all aspects of research methodology, academic writing, and biomedical statistics since training was lacking overall (Figure 2). These trainings will also add the possibility for conducting more methodologically challenging projects. However, relaxing the restrictions and requirements for master theses would still be necessary, such as allowing students to conduct bibliographical studies such as systematic reviews and meta-epidemiological studies which can be done even in hospitals with low flow of patients and still produce high-quality evidence.

Another institutional suggestion is to build an online platform that archives all Master and PhD research projects, making them available for all national and international researchers. This platform can allow national collaboration between postgraduate students in different universities and different specialties, as well as between them and other healthcare researchers nationally and internationally. In addition, organizing a national annual conference for published master theses in peerreviewed journals to be presented to younger students would spark excitement, encourage scholarly activity, and boost the attitude that research is feasible even with limited or no funding (i.e. the attitude item of least ranks in this study (Figure 1) [33]. For better applicability, this can be supplemented by publishing an Arabic concise guide targeting mentors and postgraduate students summarizing the basics of research methodology, academic writing, and medical statistics. These training and partnership attempts in addition to leadership skills lied at the heart of the recently published framework, which aimed at strengthening health research capacities in the Middle East and North Africa region [34].

The numbers of mentors in Syria dropped significantly during the years of the conflict $[6,7,35]$. However, they still hold a crucial responsibility in the process of improving research conduct among their mentees. Their expertise that accumulated over the years of war might have uncovered to them many crisis-related possible research lines that are of high priority and need to be investigated and reported. Mentors' active encouragement is also one of the most established associations with higher research output in this study and in others $[14,18]$. However, this encouragement needs to be as practical as possible, at least by frequent meetings with students and critical revisions of each phase of the projects. Another suggestion to overcome this lack of supervisors in Syria is to allow long-distance mentoring by experts in other countries [36], especially that more than half of the papers published by Syrians are done in collaboration with external institution [37]. This can additionally address the barriers of internet connectivity and language limitations as well as the lack of access to medical journals.

Page $7 / 20$ 
Residents also have their share of the responsibility, the first step of which may be to collaborate with colleagues to provide scientific support, conduct nation-wide studies, and reduce efforts duplication. These collaborations can take place between colleagues from the same specialty in two different institutions or across disciplines to provide a more translational and multifaceted analysis of health problems. Another advice isto get involved in other research studies before their master theses, because it was shown that medical students who were involved in research projects had superior research productivity after graduation $[23,38]$. Furthermore, cooperating between post-graduate students and medical undergraduate students who are interested in the same specialty may reduce the time burden for postgraduates and create additional opportunities for undergraduates to participate in the master thesis publication. The suggested platform for studies' registration above can play a pivotal role in creating these collaborations.

As a limitation, we can argue that the data in this survey study were collected using a self-reported online questionnaire. However, the individualized communication of the survey by chief residents with their respective residents' groups should have maximized recruitment and improved the quality of reporting. Therefore, the current analysis that captured the opinions of nearly a quarter of the whole targeted population in all of Syria, fulfilled the goal to assess postgraduate students' attitudes, barriers and practices in research, and to suggest fact-based solutions that could save a lot of the currently wasted efforts by pushing master theses projects towards publication.

\section{Conclusion}

Even with the positive attitudes among students, making a research projects a requirement for medical higher education programs was not enough on its own to enhance research conduct, knowledge and practices. However, improvement may be possible with coordinated low-cost institutional and individual efforts. Universities should provide further, practical, and more flexible training opportunities, activate long-distance mentorship, and encourage collaboration among students from different specialties, universities, and study phases. Mentors should create opportunities and provide actual support for their mentees. Finally, postgraduates should take part in several research projects, seek help when needed, and follow self-paced learning whenever possible.

\section{Declarations}

\section{Ethics approval and consent to participate}

Ethical approval for this study was obtained through Damascus University, and it complies with the declaration of Helsinki 1975 , as revised in 2008. Participants were informed about the aims of the study and were asked to provide their consent to participate at the beginning of the questionnaire. Participation was completely voluntary, with the assurance of confidentiality.

\section{Consent for publication}

All participants gave their consent to anonymously publish their entered data.

\section{Availability of data and materials}

The dataset supporting the conclusions of this article is available and can be submitted/uploaded upon request.

\section{Competing interests}

None of the authors has conflicts to be declared. 


\section{Funding}

This study was not funded by any party.

\section{Authors' contributions}

IH prepared the online questionnaire. $\mathrm{IH}, \mathrm{LHK}, \mathrm{SA}, \mathrm{MH}$, and OA collected the data from the different universities. SA and LHK drafted the introduction and the methods sections respectively. $\mathrm{MH}, \mathrm{LHK}$ and $\mathrm{IH}$ analyzed the data and drafted the results section. OA, MH, LHK and IH drafted the discussion. FA and MYH supervised data collection and analysis and provided insights for the discussion. All authors critically revised and approved the final version of the manuscript.

\section{Acknowledgments}

Authors would like to acknowledge the team who developed the questionnaire in a previous study [12]. They are also thankful to Bahaa Alhaffar, Marah Alsalkini and Thuraya Alaryan for contributing some ideas to the introduction and discussion.

\section{Geolocation information}

The study covered six universities in the five major cities in Syria.

\section{References}

1. Sahloul MZ, Monla-Hassan J, Sankari A, Kherallah M, Atassi B, Badr S, Abbara A, Sparrow A: War is the Enemy of Health. Pulmonary, Critical Care, and Sleep Medicine in War-Torn Syria. Annals of the American Thoracic Society 2016, 13(2):147155.

2. West CP, Dyrbye LN, Sinsky C, Trockel M, Tutty M, Nedelec L, Carlasare LE, Shanafelt TD: Resilience and Burnout Among Physicians and the General US Working Population. JAMA Network Open 2020, 3(7):e209385-e209385.

3. Shanafelt TD, Boone S, Tan L, Dyrbye LN, Sotile W, Satele D, West CP, Sloan J, Oreskovich MR: Burnout and satisfaction with work-life balance among US physicians relative to the general US population. Arch Intern Med 2012, 172(18):13771385.

4. Alhaffar BA, Abbas G, Alhaffar AA: The prevalence of burnout syndrome among resident physicians in Syria. Journal of occupational medicine and toxicology (London, England) 2019, 14:31.

5. Mohamad O, AlKhoury N, Abdul-Baki M-N, Alsalkini M, Shaaban R: Workplace violence toward resident doctors in public hospitals of Syria: prevalence, psychological impact, and prevention strategies: a cross-sectional study. Human Resources for Health 2021, 19(1):8.

6. Syria 'the most dangerous place on earth for healthcare providers' - study

[https://www.theguardian.com/world/2017/mar/15/syria-conflict-study-condemns-weaponisation-of-healthcare]

7. Syrias Neighbors Must Let Doctors Practice [https://phr.org/news/syrias-neighbors-must-let-doctors-practice/]

8. Fouad FM, Sparrow A, Tarakji A, Alameddine M, El-Jardali F, Coutts AP, El Arnaout N, Karroum LB, Jawad M, Roborgh S et al: Health workers and the weaponisation of health care in Syria: a preliminary inquiry for The Lancet-American University of Beirut Commission on Syria. The Lancet 2017, 390(10111):2516-2526.

9. Diab MM, Taftaf RM, Arabi M: Research productivity in Syria: Quantitative and qualitative analysis of current status. Avicenna journal of medicine 2011, 1(1):4-7.

10. Matar HE, Almerie MQ, Adams CE, Essali A: Publications indexed in Medline and Embase originating from the Syrian Arab Republic: a survey. Eastern Mediterranean health journal $=$ La revue de sante de la Mediterranee orientale $=$ al-Majallah alsihhiyah li-sharq al-mutawassit 2009, 15(3):648-652. 
11. Alhaffar MBA, Albarshah M, Alhaffar MAA: Addressing the Problems and Challenges of Medical Research During the Syrian Crisis; 2020.

12. Turk T, Al Saadi T, Alkhatib M, Hanafi I, Alahdab F, Firwana B, Koudsi M, Al-Moujahed A: Attitudes, barriers, and practices toward research and publication among medical students at the University of Damascus, Syria. Avicenna journal of medicine 2018, 8(1):24-33.

13. Al Saadi T, Abbas F, Turk T, Alkhatib M, Hanafi I, Alahdab F: Medical research in war-torn Syria: medical students' perspective. Lancet (London, England) 2018, 391(10139):2497-2498.

14. Mitwalli HA, Al Ghamdi KM, Moussa NA: Perceptions, attitudes, and practices towards research among resident physicians in training in Saudi Arabia. Eastern Mediterranean health journal = La revue de sante de la Mediterranee orientale = al-Majallah al-sihhiyah li-sharq al-mutawassit 2014, 20(2):99-104.

15. Benamer HT, Bakoush O: Arab nations lagging behind other Middle Eastern countries in biomedical research: a comparative study. BMC medical research methodology 2009, 9:26.

16. El Rassi R, Meho LI, Nahlawi A, Salameh JS, Bazarbachi A, AkI EA: Medical research productivity in the Arab countries: 2007-2016 bibliometric analysis. J Glob Health 2018, 8(2):020411.

17. Bilal M, Haseeb A, Mari A, Ahmed S, Sher Khan MA, Saad M: Knowledge, Attitudes, and Barriers Toward Research Among Medical Students of Karachi. Cureus 2019, 11(9):e5599.

18. Memarpour M, Fard AP, Ghasemi R: Evaluation of attitude to, knowledge of and barriers toward research among medical science students. Asia Pacific family medicine 2015, 14(1):1.

19. Woolf SH, Grol R, Hutchinson A, Eccles M, Grimshaw J: Clinical guidelines: potential benefits, limitations, and harms of clinical guidelines. Bmj 1999, 318(7182):527-530.

20. Khan $\mathrm{H}$, Khan S, Iqbal A: Knowledge, attitudes and practices around health research: the perspective of physicians-intraining in Pakistan. BMC medical education 2009, 9:46.

21. What it's like to be one of the few doctors in war-torn Syria [https://www.statnews.com/2016/05/26/doctors-war-tornsyria/]

22. Habineza H, Nsanzabaganwa C, Nyirimanzi N, Umuhoza C, Cartledge K, Conard C, Cartledge P: Perceived attitudes of the importance and barriers to research amongst Rwandan interns and pediatric residents - a cross-sectional study. BMC medical education 2019, 19(1):4.

23. Gill S, Levin A, Djurdjev O, Yoshida EM: Obstacles to residents' conducting research and predictors of publication. Academic medicine : journal of the Association of American Medical Colleges 2001, 76(5):477.

24. Ullrich N, Botelho CA, Hibberd P, Bernstein $\mathrm{HH}$ : Research during pediatric residency: predictors and resident-determined influences. Academic medicine : journal of the Association of American Medical Colleges 2003, 78(12):1253-1258.

25. Alhamid N, Almounayer N, Alsabbagh B, Atassi B: Case reports and research productivity among Syrian medical students: Review, reality, and suggested solutions. Avicenna journal of medicine 2015, 5(4):101-105.

26. Atassi B: Comments on: "Case reports and research productivity among Syrian medical students: Review, reality, and suggested solutions". Avicenna journal of medicine 2016, 6(2):61-63.

27. Courses in Clinical Research - Office of clinical research [https://ocr.od.nih.gov/courses/ippcr.html]

28. Clinical Center IPPCR course brings research training to war zone

[https://clinicalcenter.nih.gov/about/news/newsletter/2017/apr2017/story-april-06-syria.html]

29. Sabouni A, Bdaiwi Y, Janoudi SL, Namous LO, Turk T, Alkhatib M, Abbas F, Yafı RZ: Multiple strategy peer-taught evidencebased medicine course in a poor resource setting. BMC medical education 2017, 17(1):82.

30. Sabouni A, Chaar A, Bdaiwi Y, Masrani A, Abolaban H, Alahdab F, Firwana B, Al-Moujahed A: An online academic writing and publishing skills course: Help Syrians find their voice. Avicenna journal of medicine 2017, 7(3):103-109.

31. Alahdab F, Alabed S, Al-Moujahed A, Al Sallakh MA, Alyousef T, Alsharif U, Fares M, Murad MH: Evidence-based medicine: a persisting desire under fire. Evidence-based medicine 2017, 22(1):9-11. 
32. Alahdab F, Firwana B, Hasan R, Sonbol MB, Fares M, Alnahhas I, Sabouni A, Ferwana M: Undergraduate medical students' perceptions, attitudes, and competencies in evidence-based medicine (EBM), and their understanding of EBM reality in Syria. BMC Res Notes 2012, 5:431.

33. Santucci AK, Lingler JH, Schmidt KL, Nolan BA, Thatcher D, Polk DE: Peer-mentored research development meeting: a model for successful peer mentoring among junior level researchers. Acad Psychiatry 2008, 32(6):493-497.

34. El Achi N, Papamichail A, Rizk A, Lindsay H, Menassa M, Abdul-Khalek RA, Ekzayez A, Dewachi O, Patel P: A conceptual framework for capacity strengthening of health research in conflict: the case of the Middle East and North Africa region. Globalization and Health 2019, 15(1):81.

35. Milton S: Syrian higher education during conflict: Survival, protection, and regime security. International Journal of Educational Development 2019, 64:38-47.

36. Nguyen A, Rhodes S: Strategies for Successful Long-Distance Mentoring. Health Behavior Research 2019, 2(4):5-5.

37. Brimo Alsaman MZ, Sallah H, Badawi R, Ghawi A, Shashaa MN, Haj Kassem L, Ghazal A: Syrian medical, dental and pharmaceutical publication in the last decade: A bibliometric analysis. Annals of Medicine and Surgery 2021, 66:102441.

38. Reinders JJ, Kropmans TJ, Cohen-Schotanus J: Extracurricular research experience of medical students and their scientific output after graduation. Med Educ 2005, 39(2):237.

\section{Tables}

Table 1: Composition and demographic information of the participants. 
Table 1: Composition and demographic information of the participants.

$\begin{array}{lll}\text { Factors } & \mathrm{n}(\%) & \text { Response rate (total=21.5\%) }\end{array}$

\begin{tabular}{|c|c|c|}
\hline Gender & & \\
\hline Male & $162(37.8)$ & - \\
\hline Female & $267(62.2)$ & - \\
\hline Year of postgraduate study & & \\
\hline 1st year & $48(11.2)$ & - \\
\hline 2nd year & $147(34.3)$ & - \\
\hline 3rd year & 157 (36.6) & - \\
\hline 4 th year & $74(17.2)$ & - \\
\hline 5 th year & $3(0.7)$ & - \\
\hline Year of study & & \\
\hline Early registration & $105(24.5)$ & - \\
\hline Normal registration & $242(56.4)$ & - \\
\hline Late registration & $82(19.1)$ & - \\
\hline University & & \\
\hline Damascus University & $190(44.3)$ & $26.5 \%$ \\
\hline University of Aleppo & $89(20.8)$ & $23.0 \%$ \\
\hline Tishreen University & $117(27.3)$ & $20.9 \%$ \\
\hline University of Hama & $10(2.3)$ & $35.7 \%$ \\
\hline Al-Baath University & $10(2.3)$ & $12.3 \%$ \\
\hline Syrian Virtual University & $13(3.0)$ & $7.6 \%$ \\
\hline Specialties groups & & \\
\hline Clinics specialties & $56(13.1)$ & $34.1 \%$ \\
\hline Surgical specialties & $60(13.9)$ & $11.0 \%$ \\
\hline Internal medicine specialties & $103(24.0)$ & $34.5 \%$ \\
\hline Translational specialties & $41(9.6)$ & $46.1 \%$ \\
\hline Pharmacy & $56(13.1)$ & $22.1 \%$ \\
\hline Dentistry & $100(23.3)$ & $23.8 \%$ \\
\hline Medical education & $13(3.0)$ & $7.6 \%$ \\
\hline Internet connection Accessibilit & & \\
\hline Low quality & $281(65.5)$ & - \\
\hline High quality & $148(34.5)$ & - \\
\hline English language skills - writin & & \\
\hline Poor or intermediate & $236(55)$ & - \\
\hline Good or Excellent & $193(45)$ & - \\
\hline English language skills - readin & & \\
\hline Poor or intermediate & $151(35.2)$ & - \\
\hline Good or Excellent & $278(64.8)$ & - \\
\hline Sources of education/training & & \\
\hline No training & $188(43.8)$ & - \\
\hline University training & $108(25.2)$ & - \\
\hline Self-paced training & $133(31)$ & - \\
\hline Encouraged by mentors to part & & \\
\hline No & $97(22.6)$ & - \\
\hline Yes & $332(77.4)$ & - \\
\hline
\end{tabular}

Table 2: Experience of participants and their motivations and practical limitations regarding conducting and publishing research. 
Table 2: Experience of participants and their motivations and practical limitations regarding conducting and publishing research

\begin{tabular}{|c|c|c|c|}
\hline Question & $\mathbf{N}(\%)$ & Question & $\mathbf{N}(\%)$ \\
\hline \multicolumn{2}{|l|}{$\begin{array}{l}\text { Number of research projects participated in } \\
\text { (total } \mathrm{n}=429 \text { ) }\end{array}$} & \multicolumn{2}{|c|}{$\begin{array}{l}\text { Number of scientific papers submitted for publication } \\
\text { (total } n=429 \text { ) }\end{array}$} \\
\hline Never did & $\begin{array}{l}304 \\
(70.9)\end{array}$ & Never did & $374(87.2)$ \\
\hline One & $\begin{array}{l}75 \\
(17.5)\end{array}$ & One & $34(7.9)$ \\
\hline Two & 25 & Two & $10(2.3)$ \\
\hline Three & $\begin{array}{l}10 \\
(2.3)\end{array}$ & Three & $3(0.7)$ \\
\hline More than three & 15 & More than three & $8(1.9)$ \\
\hline \multicolumn{2}{|c|}{$\begin{array}{l}\text { Types of research projects participated in } \\
\text { (total } n=172 \text { running projects) }\end{array}$} & \multicolumn{2}{|c|}{$\begin{array}{l}\text { Types of scientific papers submitted for publication } \\
\text { (total } n=75 \text { submitted papers) }\end{array}$} \\
\hline Laboratory based & $\begin{array}{l}19 \\
(11)\end{array}$ & Laboratory based & $5(6.7)$ \\
\hline case report/case series & $\begin{array}{l}57 \\
(33.1)\end{array}$ & case report/case series & $28(37.4)$ \\
\hline cross-sectional & $\begin{array}{l}21 \\
(12.2)\end{array}$ & cross-sectional & $9(12)$ \\
\hline case-control & $\begin{array}{l}16 \\
(9.3)\end{array}$ & case-control & $3(4)$ \\
\hline cohort & $8(4.7)$ & cohort & $4(5.3)$ \\
\hline Randomized control trials & $8(4.7)$ & Randomized control trials & $4(5.3)$ \\
\hline systematic review & $\begin{array}{l}14 \\
(8.1)\end{array}$ & systematic review & $4(5.3)$ \\
\hline other & $\begin{array}{l}29 \\
(16.9)\end{array}$ & other & $18(24)$ \\
\hline \multicolumn{2}{|l|}{$\begin{array}{l}\text { Reasons why it is important to participate in } \\
\text { research (total } n=429 \text { ) }\end{array}$} & \multicolumn{2}{|c|}{ Main motivation to consider publication (total $n=47$ ) } \\
\hline An important skill to learn & $\begin{array}{l}115 \\
(26.8)\end{array}$ & Relay information. & $17(36.2)$ \\
\hline To relay information & $\begin{array}{l}100 \\
(23.3)\end{array}$ & Career progression. & $16(34)$ \\
\hline To improve career. & $\begin{array}{l}68 \\
(15.9)\end{array}$ & Personal interest. & $11(23.4)$ \\
\hline $\begin{array}{l}\text { To improve the research situation in } \\
\text { my country. }\end{array}$ & $\begin{array}{l}63 \\
(14.7)\end{array}$ & \multicolumn{2}{|l|}{$\begin{array}{l}\text { Reasons for not submitting scientific papers for } \\
\text { publication after writing (total } n=66 \text { ) }\end{array}$} \\
\hline For personal interest. & $\begin{array}{l}51 \\
(11.9)\end{array}$ & Lack of experience in academic writing & $20(30.3)$ \\
\hline To keep up with peers & $\begin{array}{l}21 \\
(4.9)\end{array}$ & Lack of guidance and supervision & $18(27.3)$ \\
\hline It is not important. & $\begin{array}{l}11 \\
(2.5)\end{array}$ & Lack of time. & $18(27.3)$ \\
\hline $\begin{array}{l}\text { Reasons for not participating in } \\
\text { research (total } n=286 \text { ) }\end{array}$ & & Research team problems & $7(10.6)$ \\
\hline Lack of guidance and supervision & $\begin{array}{l}118 \\
(41.3)\end{array}$ & \multicolumn{2}{|c|}{$\begin{array}{l}\text { Outcome of paper submissions (total } n=40 \text { submitted } \\
\text { papers) }\end{array}$} \\
\hline $\begin{array}{l}\text { Did not have the opportunity to take } \\
\text { part in research }\end{array}$ & $\begin{array}{l}105 \\
(36.7)\end{array}$ & None were accepted for publication & $12(30)$ \\
\hline Lack of time & $\begin{array}{l}38 \\
(13.3)\end{array}$ & Only few were accepted for publication & $11(27.5)$ \\
\hline Not interested in doing research & $20(7)$ & Most were accepted for publication & $9(22.5)$ \\
\hline & & All were accepted for publication & $8(20)$ \\
\hline
\end{tabular}

Table 3: The association between the attitudes and barriers and participating in research projects or submitting papers for publication 
Table 4: Associations between conducting research projects/submitting scientific papers and participants' characteristics. 
Table 3: The association between the attitudes and barriers and participating in research projects or submitting papers for publication

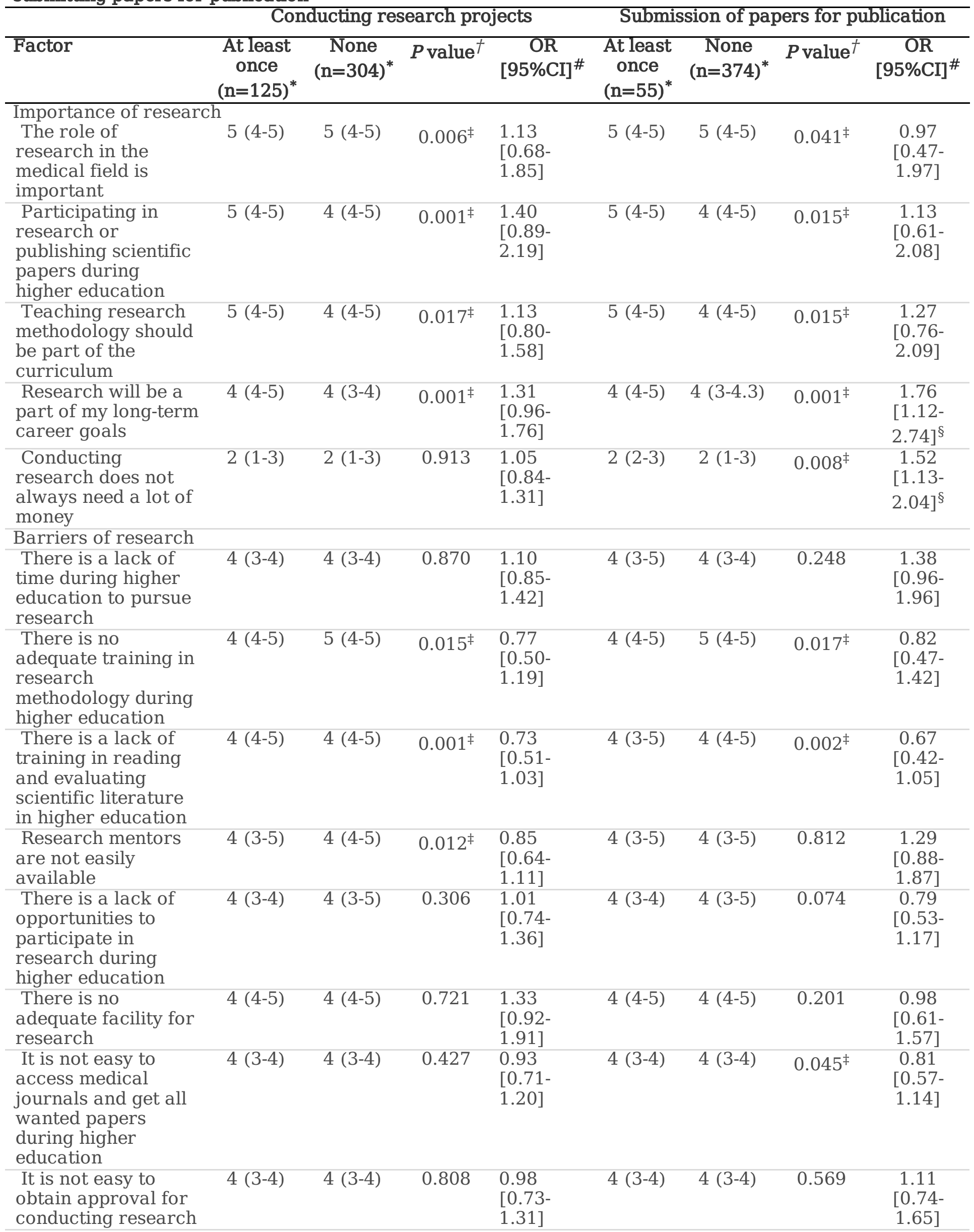




\begin{tabular}{|c|c|c|c|c|c|c|c|c|}
\hline $\begin{array}{l}\text { Not enough } \\
\text { rewards/motivations } \\
\text { to participate in } \\
\text { research }\end{array}$ & $4(3-5)$ & $4(3-5)$ & 0.835 & $\begin{array}{l}1.15 \\
{[0.87-} \\
1.49]\end{array}$ & $4(3-5)$ & $4(3-5)$ & 0.304 & $\begin{array}{c}1.03 \\
{[0.72-} \\
1.47]\end{array}$ \\
\hline $\begin{array}{l}\text { There are language } \\
\text { limitations to } \\
\text { conduct research }\end{array}$ & $3(2-4)$ & $3(2-4)$ & 0.190 & $\begin{array}{l}0.88 \\
{[0.69-} \\
1.10]\end{array}$ & $3(2-3)$ & $3(2-4)$ & $0.005^{\ddagger}$ & $\begin{array}{c}0.69 \\
{[0.49-} \\
0.94]^{\S}\end{array}$ \\
\hline
\end{tabular}

* The ranks are presented as median (1st quartile- 3rd quartile); $†$ Mann-Whitney U test; $\neq$ Significant at the level of 0.05 for the major categorization; \# Binary logistic regression results; \& Significant independent predictor; OR: Odds ratio; CI: Confidence interval 
Table 4: Associations between conducting research projects/submitting scientific papers and participants' characteristics $(n=429)$

Factor

\section{Conducting research projects \\ Submission of papers for publication}

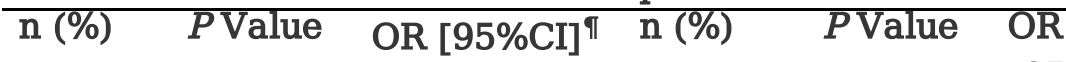

$[95 \% \mathrm{CI}]^{\Uparrow}$

\begin{tabular}{|c|c|c|c|c|c|c|}
\hline By gender & & $0.584^{*}$ & & & $0.657^{*}$ & \\
\hline Female $(n=267)$ & $\begin{array}{l}75 \\
(28.1)\end{array}$ & & & $\begin{array}{l}36 \\
(13.5)\end{array}$ & & \\
\hline Male $(n=162)$ & $\begin{array}{l}50 \\
(30.9)\end{array}$ & & $\begin{array}{l}1.08 \text { [0.66- } \\
1.77]\end{array}$ & $\begin{array}{l}19 \\
(11.7)\end{array}$ & & $\begin{array}{l}0.89 \\
{[0.45-} \\
1.78]\end{array}$ \\
\hline By Year of study & & $<0.001^{\dagger \ddagger}$ & & & $0.001^{\dagger \ddagger}$ & \\
\hline Early registration $(\mathrm{n}=105)$ & $\begin{array}{l}23 \\
(21.9)\end{array}$ & $0.065^{*}$ & & $15(14.3)$ & $0.616^{*}$ & \\
\hline Normal registration $(\mathrm{n}=242)$ & $58(24)$ & $0.010^{*}$ & $\begin{array}{l}0.55[0.26- \\
1.18]\end{array}$ & $20(8.3)$ & $0.002^{* \S}$ & $\begin{array}{l}0.55 \\
{[0.22-} \\
1.38]\end{array}$ \\
\hline Late registration $(\mathrm{n}=82)$ & $\begin{array}{l}44 \\
(53.7)\end{array}$ & $<0.001^{* \S}$ & $\begin{array}{l}2.24[0.94- \\
5.31]\end{array}$ & $20(24.4)$ & $0.001^{* \S}$ & $\begin{array}{l}1.87 \\
{[0.66-} \\
5.32]\end{array}$ \\
\hline By University ${ }^{\square}$ & & $0.230^{\dagger}$ & & & $0.239^{\dagger}$ & \\
\hline Damascus University $(n=190)$ & $\begin{array}{l}48 \\
(25.3)\end{array}$ & $0.220^{*}$ & & $18(9.5)$ & $0.096^{*}$ & \\
\hline University of Aleppo $(\mathrm{n}=89)$ & $\begin{array}{l}24 \\
(27.0)\end{array}$ & $0.791^{*}$ & $\begin{array}{l}1.43[0.74- \\
2.76]\end{array}$ & $\begin{array}{l}13 \\
(14.6)\end{array}$ & $0.468^{*}$ & $\begin{array}{l}2.06 \\
{[0.87-} \\
4.83]\end{array}$ \\
\hline Tishreen University $(\mathrm{n}=117)$ & $\begin{array}{l}40 \\
(34.2)\end{array}$ & $0.112^{*}$ & $\begin{array}{l}2.00[1.08- \\
3.68]^{\#}\end{array}$ & $\begin{array}{l}18 \\
(15.4)\end{array}$ & $0.245^{*}$ & $\begin{array}{l}2.04 \\
{[0.89-} \\
4.68]\end{array}$ \\
\hline By Specialties groups & & $0.011^{\dagger \ddagger}$ & & & $0.003^{\dagger \ddagger}$ & \\
\hline Clinics specialties $(\mathrm{n}=56)$ & $\begin{array}{l}12 \\
(21.4)\end{array}$ & $0.208^{*}$ & & $9(16.1)$ & $0.399^{*}$ & \\
\hline Surgical specialties $(\mathrm{n}=60)$ & $\begin{array}{l}16 \\
(26.7)\end{array}$ & $0.760^{*}$ & $\begin{array}{l}1.13[0.42- \\
3.07]\end{array}$ & $9(15.0)$ & $0.538^{*}$ & $\begin{array}{l}0.68 \\
{[0.21-} \\
2.20]\end{array}$ \\
\hline Internal medicine specialties $(n=103)$ & $\begin{array}{l}20 \\
(19.4)\end{array}$ & $0.013^{*}$ & $\begin{array}{l}1.50[0.55- \\
4.11]\end{array}$ & $\begin{array}{l}13 \\
(12.6)\end{array}$ & $1.000^{*}$ & $\begin{array}{l}1.08 \\
{[0.33-} \\
3.53]\end{array}$ \\
\hline Translational specialties $(\mathrm{n}=41)$ & $\begin{array}{l}11 \\
(26.8)\end{array}$ & $0.857^{*}$ & $\begin{array}{l}1.88[0.66- \\
5.33]\end{array}$ & $7(17.1)$ & $0.458^{*}$ & $\begin{array}{l}1.49 \\
{[0.44-} \\
5.05]\end{array}$ \\
\hline Pharmacy $(\mathrm{n}=56)$ & $\begin{array}{l}23 \\
(41.1)\end{array}$ & $0.041^{*}$ & $\begin{array}{l}2.86[1.07- \\
7.70]^{\#}\end{array}$ & $6(10.7)$ & $0.830^{*}$ & $\begin{array}{l}0.58 \\
{[0.16-} \\
2.07]\end{array}$ \\
\hline Dentistry $(n=100)$ & $36(36)$ & $0.102^{*}$ & $\begin{array}{l}3.00[1.21- \\
7.47]^{\#}\end{array}$ & $5(5)$ & $0.006^{*}$ & $\begin{array}{l}0.34 \\
{[0.09-} \\
1.21]\end{array}$ \\
\hline Medical education $(n=13)$ & $\begin{array}{l}7 \\
(53.8)\end{array}$ & $0.062^{*}$ & $\begin{array}{l}5.09 \text { [1.18- }^{-1} \\
22.09]^{\#}\end{array}$ & $6(46.2)$ & $0.003^{*}$ & $\begin{array}{l}4.79 \\
{[1.00-} \\
22.96]\end{array}$ \\
\hline By Internet connection Accessibility & & $0.010^{*} \ddagger$ & & & $0.004^{* \ddagger}$ & \\
\hline Low quality $(\mathrm{n}=281)$ & $\begin{array}{l}70 \\
(24.9)\end{array}$ & & & $26(9.3)$ & & \\
\hline High quality $(\mathrm{n}=148)$ & $\begin{array}{l}55 \\
(37.2)\end{array}$ & & $\begin{array}{l}1.45[0.89- \\
2.38]\end{array}$ & $\begin{array}{l}29 \\
(19.6)\end{array}$ & & $\begin{array}{l}1.96 \\
{[1.02-} \\
3.77]^{\#}\end{array}$ \\
\hline English language skills (writing) & & $<0.001^{* \ddagger}$ & & & $<0.001^{* \ddagger}$ & \\
\hline Poor or intermediate $(\mathrm{n}=236)$ & $\begin{array}{l}52 \\
(22.0)\end{array}$ & & & $17(7.2)$ & & \\
\hline
\end{tabular}

Page $17 / 20$ 
Good or Excellent (n=193) 73

73

$2.04[1.15-$

38

4.55

$(37.8)$

$3.61]^{\#}$

(19.7)

$[1.86-$

$11.14]^{\#}$

\begin{tabular}{|c|c|c|c|c|c|c|}
\hline $\begin{array}{l}\text { English language skills (reading and } \\
\text { comprehension) }\end{array}$ & & $0.008^{* \ddagger}$ & & & $0.365^{*}$ & \\
\hline Poor or intermediate $(\mathrm{n}=151)$ & $\begin{array}{l}32 \\
(21.2)\end{array}$ & & & $\begin{array}{l}16 \\
(10.6)\end{array}$ & & \\
\hline Good or Excellent $(n=278)$ & $\begin{array}{l}93 \\
(33.5)\end{array}$ & & $\begin{array}{l}1.01[0.54- \\
1.90]\end{array}$ & $39(14)$ & & $\begin{array}{l}0.44 \\
{[0.17-} \\
1.13]\end{array}$ \\
\hline $\begin{array}{l}\text { Sources of education/training about } \\
\text { research }\end{array}$ & & $<0.001^{\dagger \ddagger}$ & & & $<0.001^{\dagger \ddagger}$ & \\
\hline No sufficient training $(\mathrm{n}=188)$ & $\begin{array}{l}31 \\
(16.5)\end{array}$ & $<0.001^{* \S}$ & & $12(6.4)$ & $<0.001^{* \S}$ & \\
\hline University training $(\mathrm{n}=108)$ & $\begin{array}{l}39 \\
(36.1)\end{array}$ & $0.068^{*}$ & $\begin{array}{l}2.17[1.14- \\
4.15]^{\#}\end{array}$ & $14(13)$ & $1.000^{*}$ & $\begin{array}{l}3.24 \\
{[1.24-} \\
8.43]^{\#}\end{array}$ \\
\hline Self -paced training $(n=133)$ & $\begin{array}{l}55 \\
(41.4)\end{array}$ & $<0.001^{* \S}$ & $\begin{array}{l}2.68[1.48- \\
4.84]^{\#}\end{array}$ & $\begin{array}{l}29 \\
(21.8)\end{array}$ & $<0.001^{* \S}$ & $\begin{array}{l}3.64 \\
{[1.62-} \\
8.19]^{\#}\end{array}$ \\
\hline $\begin{array}{l}\text { Encouraged by mentors to participate in } \\
\text { research }\end{array}$ & & $<0.001^{* \ddagger}$ & & & $0.083^{*}$ & \\
\hline No $(n=97)$ & $\begin{array}{l}14 \\
(14.4)\end{array}$ & & & $7(7.2)$ & & \\
\hline Yes $(n=332)$ & $\begin{array}{l}111 \\
(33.4)\end{array}$ & & $\begin{array}{l}2.04[1.02- \\
4.06]^{\#}\end{array}$ & $\begin{array}{l}48 \\
(14.5)\end{array}$ & & $\begin{array}{l}1.47 \\
{[0.58-} \\
3.75]\end{array}$ \\
\hline
\end{tabular}

I Binary logistic regression results; * Fisher's exact test; + Chi-square test; $\neq$ Significant at the level of 0.05 for the major categorization; \& Significant at the level of 0.0026 for the individual subcategories' comparisons (Bonferroni correction for multiple tests 0.05/19); \# Significant independent predictor according to the regression analysis; $\square$ The three smaller universities were excluded from the analysis and the total $n=396$; OR: Odds ratio; CI: Confidence interval

\section{Figures}




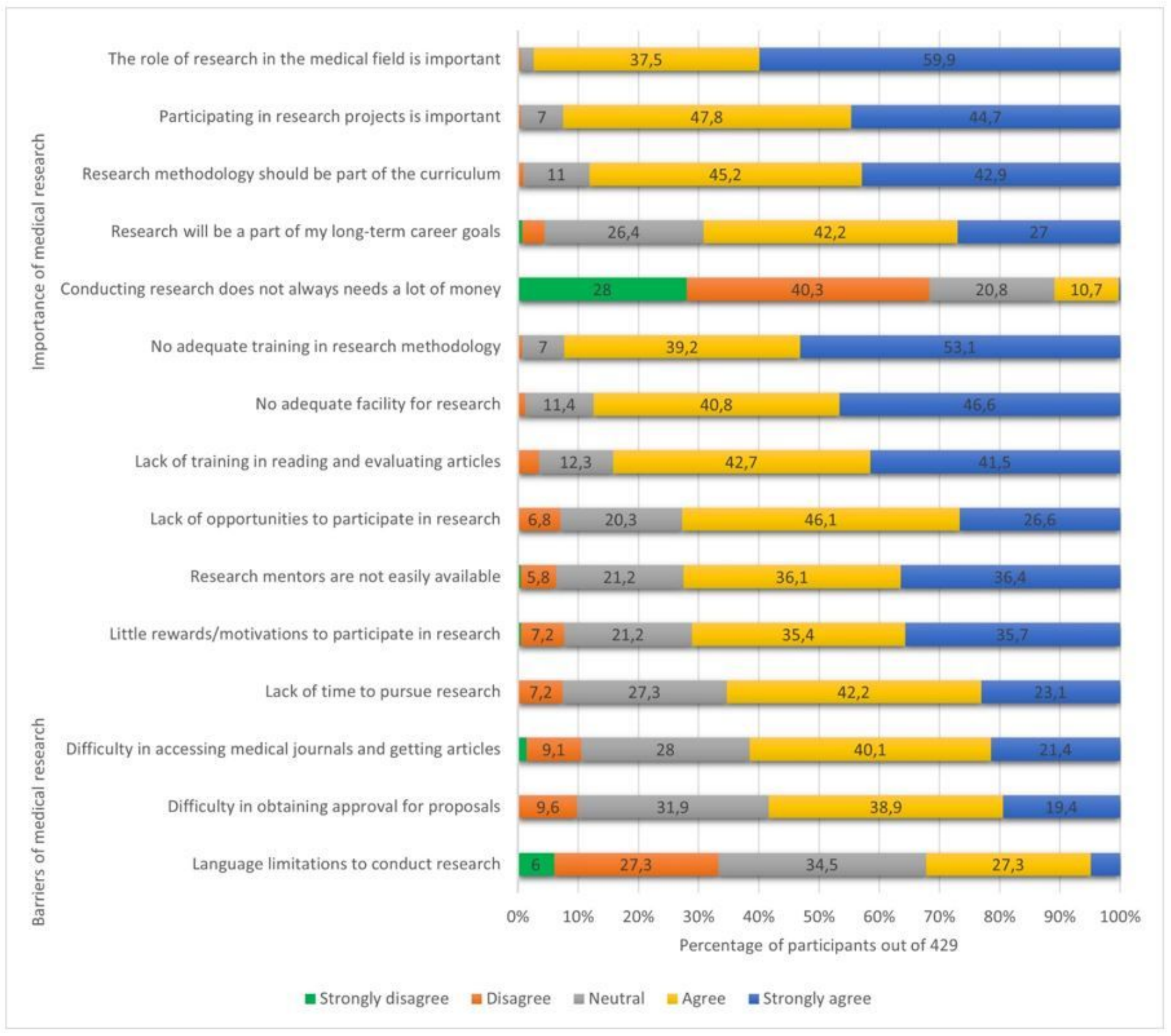

\section{Figure 1}

: Participant's personal perspectives of the importance and the barriers of research. Questions were flipped when needed to always make the agreement to the right side of the figure, then they were ordered in descending order according to the percentage of the answers "agree" and "strongly agree" combined; Percentages lower than $5 \%$ were represented but not labelled. 


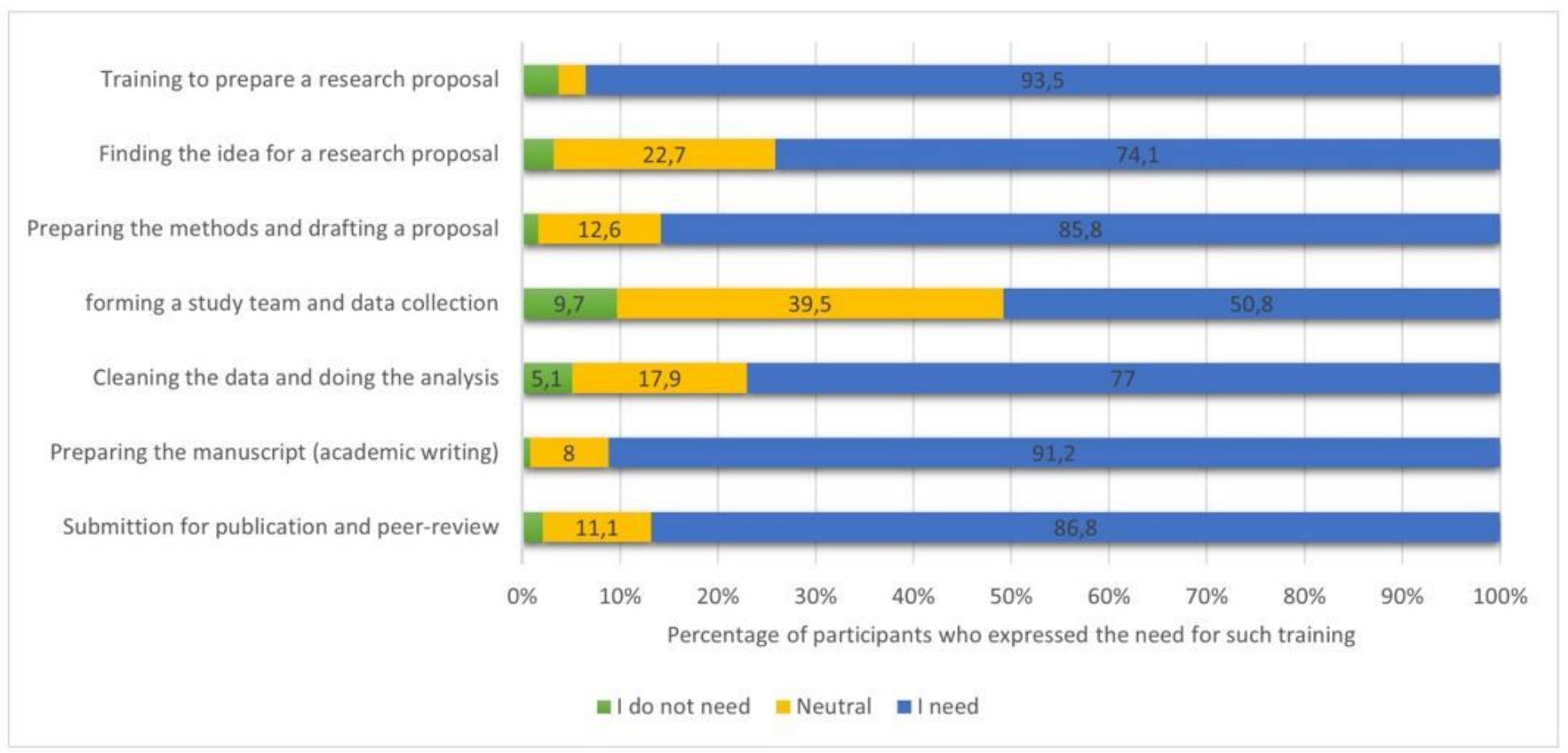

\section{Figure 2}

The training needs for preparing master theses among medical higher studies trainees. Percentages lower than $5 \%$ were represented but not labelled. 